\title{
SYSTEMS OF BASIC TILLAGE \\ IN THE CROP ROTATIONS ON THE IRRIGATED LANDS OF SOUTHERN STEPPE OF UKRAINE
}

\section{Biliaieva I. M.}

\section{INTRODUCTION}

The Steppe zone occupies southern part of the territory of Ukraine. The area of agricultural land is 17.617 million ha, of which 14.848 million ha of arable land.

Southern arid and Dry Steppe soil and ecological subzones of the Steppe zone occupy 5 million 761 thousand agricultural lands in five regions of Ukraine and Crimea, of which arable land occupies 4 million 507 thousand ha or $78.2 \%$. The soil cover is represented by chernozem southern and chestnut soils. The main area of chernozem southern $-62.6 \%$ is occupied by model subtypes, $22.2 \%$ - micelle-carbonate, $15.1 \%$ - alkaline, $25 \%$ eroded. The soils of the chestnut zone are divided into dark-chestnut and chestnut. The latter occupy a narrow strip along the Sivash with a total area of 219.4 thousand ha. To the north of the chestnut soils are dark-chestnut soils with a total area of 1270 thousand ha ${ }^{1}$.

Experimental studies were carried out in the Bilozerka naturalagricultural district of Kherson region.

The soil cover of the district is represented by dark-chestnut soils and their complexes with solonetz. They occupy $69.7 \%$ of arable land. The soils are characterized by a developed humus profile with a thickness of $52-58 \mathrm{~cm}$, a low content of humus $(1.9-2.7 \%)$, medium and heavy-loamy granulometric composition, deflation-safe, chemical and physical properties are satisfactory. On the lands irrigated from the Dnipro estuary and the Ingulets river, secondary alkalination, places of salinization and flooding of the soils are manifested ${ }^{2,3,4,5}$.

\footnotetext{
${ }_{1}^{1}$ Класифікація грунтів України. К.: Аграрна наука, 2005. 299 с.

${ }^{2}$ Система ведення сільського господарства Херсонської області. Херсон: «Айлант», 2004. $164 \mathrm{c}$.

${ }^{3}$ Балюк С. А., Ромащенко М. І., Трускавецький Р. С. Меліорація грунтів систематика, перспективи, інновації. Херсон, 2015. 667 с.

${ }_{4}^{4}$ Коваленко П. І. Інтегроване управління водними і земельними ресурсами на меліорованих територіях. Київ: Аграрна наука, 2009. 783 с.

5 Ромащенко М. І., Вожегова Р. А., Шатковський А. П. Наукові засади розвитку аграрного сектора економіки південного регіону. Херсон: Олді- плюс, 2017. 437 с.
} 
The territory of the district is located in the northern part of the Black Sea lowland on the right bank of the Dnipro River within the Upper Pliocene terrace.

Geologically, the upper terraces are composed of four horizons of loessloam thickness of $25-30 \mathrm{~m}$, dissected by 2-3 horizons of buried soils. The forests are covered by red-brown clays that lie on Neogene Pontic lime stones. Sandy and clay deposits occur between lime stones and clays ${ }^{6,7}$.

The lands of the Central experimental base of the Institute of Irrigated Agriculture of NAAS are located in eastern part of the Bilozerka district of Kherson region in the area of Ingulets irrigation system.

The soil of the experimental plot is a dark-chestnut middle-loamy secondary-alkaline silt-stone one. The granulometric composition of the studied soil is mainly represented by the large dust fraction $(38.1 \%$ in the arable layer), so they are easily susceptible to erosion processes (Table 1).

Table 1

Granulometric composition of the dark-chestnut soil of the experimental field of the Institute of Irrigated Agriculture of NAAS

\begin{tabular}{|c|c|c|c|c|c|c|c|c|c|c|}
\hline \multirow{2}{*}{$\begin{array}{l}\text { Genetic } \\
\text { horizon }\end{array}$} & \multirow{2}{*}{$\begin{array}{l}\text { Depth } \\
\text { of } \\
\text { sample } \\
\text { taking, } \\
\text { cm }\end{array}$} & \multirow{2}{*}{$\begin{array}{l}\text { Hygroscopic } \\
\text { humidity, \% }\end{array}$} & \multicolumn{6}{|c|}{ Fractions, $\mathbf{m m}$} & \multicolumn{2}{|c|}{$\begin{array}{c}\text { Sum of } \\
\text { particles, } \mathrm{mm}\end{array}$} \\
\hline & & & $\begin{array}{c}1- \\
0.25\end{array}$ & $\begin{array}{c}0.25- \\
0.05\end{array}$ & $\begin{array}{l}0.05- \\
0.01\end{array}$ & $\begin{array}{l}0.01- \\
0.005\end{array}$ & $\begin{array}{l}0.005- \\
0.001\end{array}$ & $<0.001$ & $<0.01$ & $>0.01$ \\
\hline $\begin{array}{l}\mathrm{H}(\mathrm{e}) \\
\text { arable }\end{array}$ & $10-20$ & 1.06 & 0.80 & 21.44 & 38.10 & 13.95 & 4.89 & 20.82 & 39.66 & 60.34 \\
\hline Hpi & $35-45$ & 1.10 & 0.16 & 17.74 & 41.84 & 11.59 & 5.85 & 22.82 & 40.26 & 59.74 \\
\hline $\mathrm{Phi} / \mathrm{K}$ & $48-52$ & 1.08 & 0.25 & 7.94 & 40.59 & 14.26 & 10.07 & 26.89 & 51.22 & 48.78 \\
\hline $\mathrm{Pi} / \mathrm{K}$ & $55-65$ & 1.08 & 0.32 & $\begin{array}{l}8.74 \\
\end{array}$ & 30.72 & 15.90 & 11.60 & 32.72 & 60.22 & 39.78 \\
\hline $\mathrm{P} / \mathrm{\kappa}$ & $70-80$ & 1.07 & 0.40 & 7.10 & 31.20 & 16.20 & 12.20 & 32.90 & 61.30 & 38.70 \\
\hline
\end{tabular}

Due to the fact that irrigation of the experimental plot was carried out by the waters of low mineralization with an unfavorable ratio of one - and divalent cations (irrigation waters of the Ingulets irrigation system according to the DSTU-2730-94 belong to the 2nd class - «limited suitable for irrigation»), there was observed an increased content of exchangeable sodium in the soil absorption complex of the arable layer in comparison to the non-irrigated soil.

Soil alkalinity determines unsatisfactory water-physical properties of the arable layer. The low content of water-resistant aggregates in the arable layer of the soil complicates its cultivation in the dry conditions. Under irrigation,

${ }^{6}$ Бурзі К. Е., Красутська Н. В., Синицина Н. П., Сафонова О. П.Сольовий режим грунтів Інгулецького зрошуваного масиву. Зрошуване землеробство. 1971. Вин. 12. С. 63-67.

${ }_{7}^{7}$ Балюк С. А., Ромащенко М. І., Сташук В. А. Наукові основи охорони та раціонального використання зрошуваних земель України. Київ: Аграрна наука, 2009. 620 с. 
the surface layer over-crusts, which impedes the penetration of water into the deeper horizons of the soil. The condition of the physical maturity of the alkaline soil, which determines its suitability for cultivation in the spring, is delayed, and after cultivation - lumpy surface is formed. The clods in the dry state are strong, difficult to cultivate, in addition, in such soils at the depth of 30-35 cm, a compacted illuvial layer is formed, which impedes the penetration into the deeper layers not only for water but also for the root system of plants. Thus, dark-chestnut soils under the irrigation with the waters of the Ingulets Irrigation System require anti-erosion measures and the development and improvement of their tillage with accordance to the certain conditions of the area.

The development of the system of basic tillage of the secondary-gleied irrigated, on the background of closed horizontal drainage, lands was carried out on meadow-chestnut medium-solod gley on the gleied loess soils. Their general characteristics correspond to the soils described above. Agrochemical composition of the general forms of nitrogen, phosphorus and potassium, they are close to the dark-chestnut soils.

Thus, the dark-chestnut secondary-alkaline and chernozem southern moderately-washed soils by physical, chemical and physic-chemical properties are typical soils of the meliorated agro-landscapes of Southern Steppe of Ukraine.

On the central experimental base of the Institute of Irrigated Agriculture of NAAS, a study devoted to the determination of the impact of basic tillage systems on agro physical, chemical and biological soil properties, phytosanitary conditions of crops, yields and productivity of various types of irrigated and non-irrigated crop rotations have been started since 1966.

The results of the studies, obtained in the first rotation (1966-1976) of fruit-changing crop rotation on the dark-chestnut irrigated middle-loamy soil, indicate that for 10 years of irrigation with the use of five tillage systems with a rotation of the slice to the depth of $20-22$ to $38-40 \mathrm{~cm}$ there was an increase in the content of organic matter in the soil layer of $0-40 \mathrm{~cm}$ to $111.4-111.8$ t/ha with the content of $1.97 \%$, i.e. the average annual increase averaged to $0.71-0.75 \mathrm{t} / \mathrm{ha}$.

\section{Tillage systems in the crop rotations for enterprises with developed dairy and beef cattle}

Irrigation is the most effective measure to counteract the increasing aridity of climate, especially in southern part of the Steppe zone. Approaches to tillage in crop rotations on the irrigated lands differ significantly from those on the non-irrigated ones, and they are directed to the improvement of the water regime and ensuring ecological safety at the realization of the 
natural and climatic potential of the region and genetically determined productivity of varieties and hybrids of crops ${ }^{8,9}$.

Combination for a long time in fruit-changing crop rotation with the coefficient of use of irrigated arable land of 1.25 of the deep plow tillage under the row crops - corn for grain and silage, sugar and forage beetroots, soybean, vegetable crops and alfalfa, with shallow $(12-14 \mathrm{~cm})$ disk loosening under the cereals - winter wheat, winter barley, winter rye and surface $(6-8 \mathrm{~cm})$ or sowing in the previously untilled soil in the post-harvest and post-mowing terms promoted nitrogen mobilization to a greater extent than the long-termed plowless tillage. At the differentiated system of tillage in crop rotation in comparison to the plowless shallow single-depth one $(12-14 \mathrm{~cm})$ the bulk density decreased by $6.3 \%$, the water permeability increased from 1.68 to $2.28 \mathrm{~mm} / \mathrm{min}$. (35.7\%), the content of waterproof units increased by $9.2 \%$.

Wrapping of plant residues or manure under plowing into the lower part of the cultivated layer in this crop rotation provided a higher level of humification process than introducing fresh organic matter into the top $(0-15 \mathrm{~cm})$ soil layer under plowless tillage systems, as evidenced by the results of the long-term experimental researches.

In the 8-field grain-herb-row crop rotation on the background of generally accepted irrigation regimes and organo-mineral fertilization system with the application of N180P120 and 15 tons of semi-rotten manure per 1 ha of the crop rotation contributed to the average annual increase of humus at the level of 1.28-1.57 t/ha, whereas at the long-term use (1976-2006) of the system of single-depth shallow tillage in the crop rotation the accumulation was only $0.85 \mathrm{t} / \mathrm{ha}^{10,11,12}$.

During the fifth rotation (2007-2016), alfalfa and multicomponent herb mixtures for green manure in the post-harvest period were excluded from the crop rotation, and the entire leaf-stem mass of the crop rotation was used for fertilization. As a result, the tempo of humus accumulation over this 10-year

${ }^{8}$ Вожегова Р. А., Сташук В. А., Заришняк А. С. Системи землеробства на зрошуваних землях. Київ: Аграрна наука, 2014. 359 с.

${ }_{9}^{9}$ Малярчук М. П., Нижеголенко В. М., Резніченко Н. Д., Воронюк Л. А. Системи землеробства в умовах південного посушливого та сухого степу. Збірник матеріалів Міжнародної науково-практичної конференції «Наукові засади ефективного ведення степового землеробства в умовах змін клімату» 28-29 травня 2015 р. Херсон: Грінь Д.С., 2015. C. 141-145.

${ }^{10}$ Малярчук М. П., Вожегова Р. А., Марковська О. Є. Формування систем основного обробітку грунту в агробіоценозах на меліорованих землях південної посушливої та сухо степової грунтово-екологічних підзон України. Навчальний посібник. Херсон: Айлант, 2012. $180 \mathrm{c}$.

${ }^{11}$ Малярчук М. П., Писаренко П. В., Мишукова Л. С., Малярчук А. С Котельников Д. І., Нижеголенко В. М. Ефективність мінімізованих способів основного обробітку і сівби в попередньо-необроблений грунт при вирощуванні кукурудзи на зрошуваних землях. Зрошуване землеробство: збірник наукових праць. Херсон: Айлант, 2013. Вип. 59. С. 36-38.

12 Малярчук М. П. Система обробітку грунту. Наукові основи охорони та раціонального використання зрошуваних земель України. Київ: Аграрна наука, 2009. C. 299-313. 
time span decreased in all the variants of the experiment and averaged to 0.1-0.3 t/ha, with the highest rate in the variant of the differentiated basic tillage system, where differentiated by depth plowless methods are interchanged with one slotting for the crop rotation on the depth of $38-40 \mathrm{~cm}$ during the rotation (Fig. 1).

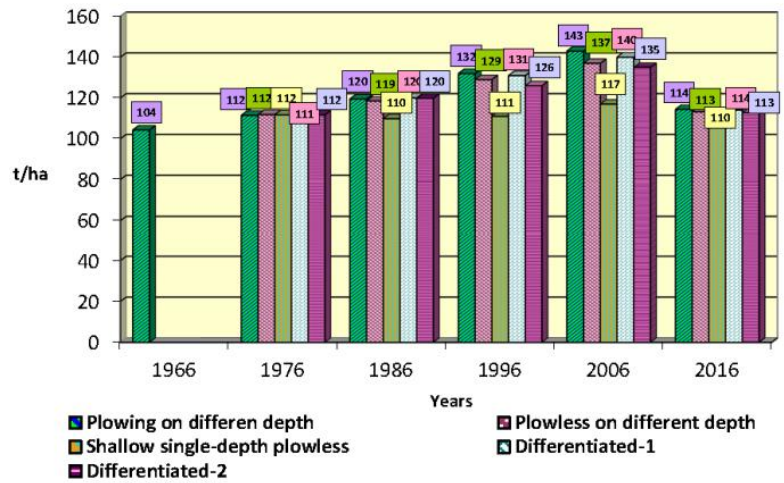

Fig. 1. Dynamics of the humus content in the $0-40 \mathrm{~cm}$ layer of dark-chestnut soil under different systems of basic tillage in 8-field fruit-changing irrigated crop rotation for the period of 1966-2016, $t / \mathrm{ha}$

In general, experimental studies of the efficiency of different systems of basic tillage of dark-chestnut soil provided the possibility to find out that the highest productivity of the eight-crop fruit-changing rotation is provided by the differentiated system of basic tillage, in which the plowing to the depth of 20-22 to 30-32 cm under the row crops inter-changes with plowless tillage to the depth of 12-16 cm under winter wheat and spring barley on the background of one slotting $(38-40 \mathrm{~cm})$ for the rotation under barley with alfalfa.

The use of the differentiated basic tillage system increased the cost recovery by $9.4 \%$ due to the increase in the crop rotation productivity up to $13.0 \mathrm{t} / \mathrm{ha}$ of forage units against $11.5 \mathrm{t} / \mathrm{ha}$ of forage units at the plowless single-depth shallow $(12-14 \mathrm{~cm})$ system of basic tillage (Table 2). 
Table 2

\section{Productivity of 8-field fruit-changing crop rotation at irrigation under the different systems of basic tillage of dark-chestnut soil of the experimental field of the Institute of Irrigated Agriculture of NAAS}

\begin{tabular}{|c|c|c|c|c|c|}
\hline \multirow{2}{*}{ Crop of the rotation } & \multicolumn{5}{|c|}{ Productivity by the systems, $t / h a$ of forage units } \\
\hline & 1 & 2 & 3 & 4 & 5 \\
\hline $\begin{array}{c}\text { Annual crops } \\
\text { for green forage }+ \text { alfalfa (hay) }\end{array}$ & 13.6 & 13.1 & 12.3 & 13.6 & 13.2 \\
\hline Alfalfa of the $2^{\text {nd }}$ year (hay) & 12.1 & 12.1 & 12.2 & 12.0 & 12.1 \\
\hline Alfalfa of the $3^{\text {nd }}$ year (hay) & 9.8 & 8.4 & 8.4 & 9.7 & 8.3 \\
\hline Winter wheat + post-harvest & 6,9 & 71,5 & 70,8 & 71,2 & 70,3 \\
\hline (grain + green mass) & $\overline{39,2}$ & $\overline{402}$ & $\overline{376}$ & $\overline{400}$ & $\overline{399}$ \\
\hline Sugar-beet & 6.6 & 5.9 & 5.5 & 6.9 & 6.6 \\
\hline Corn for silage & 45.6 & 42.3 & 38.3 & 46.6 & 47.1 \\
\hline Winter wheat + post-harvest & 65,9 & 70,2 & 72,9 & 68,3 & 67,1 \\
\hline (grain + green mass $)$ & $\overline{492}$ & $\overline{517}$ & $\overline{505}$ & $\overline{499}$ & $\overline{482}$ \\
\hline Grain corn & 8.9 & 7.7 & 7.5 & 9.1 & 8.7 \\
\hline $\begin{array}{l}\text { Crop rotation productivity, } \\
\text { forage units }\end{array}$ & 12.8 & 11.8 & 11.5 & 13.0 & 12.6 \\
\hline
\end{tabular}

Note: 1-plowing at different depth, 2-plowless at different depth, 3-shallow single-depth plowless, 4-differentiated-1 with plowing under the row crops and one slotting per rotation, 5-differentiated-2 with plowing under the row crops

The increase of the coefficient of arable land use in the irrigated crop rotations up to 1.75 at the expense of inter-crops in early spring, post-mowing and post-harvest periods makes it possible to increase the efficiency of irrigated hectare and to obtain more products at the same costs for the construction of irrigation network and its exploitation, as well as provides additional accumulation of organic matter, which improves the physical and chemical properties of the soil and activates beneficial microorganisms activity. Owing to inter-crops of leguminous and cabbage crops, nitrogen reserves are increasing, and the weediness of the following crops is reduced ${ }^{3}$.

In the arable soil layer, after sowing of the inter-crops, where the recommended irrigation regime has been maintained, there is sufficient water for its qualitative preparation to sowing. The decisive value for the crops cultivation in the post-mowing and post-harvest periods is not the depth, but the quality of pre-sowing tillage, that is, good seed wrapping and sufficient compaction of the seed bed for better provision with water of the crops with large seeds.

Taking into account that their growth and development is limited in time, it is advisable to observe these conditions. Compliance with the necessary agrotechnical requirements enables the use of combined tillage aggregates for simultaneous tillage, sowing and rolling.

${ }_{13}$ Малярчук М. П. Формування систем обробітку грунту в сівозмінах на меліорованих землях Південного Степу України. Посібник Українського хлібороба. 2014. 
As a result of the introduction of differentiated system of basic tillage in the 4-field row crop rotation with the coefficient of use of irrigated arable land of 1.75 , the high efficiency of its saturation with early spring, postmowing and post-harvest crops has been established.

The loosening effect of the root system, the protective effect of the vegetative mass of plants in the spring and summer period and the effect of post-harvest residues of inter-crops, directed to the soil improvement, contributed to the reduction of the bulk density of dark-chestnut soil in the layer of $0-30 \mathrm{~cm}$ from 1.28 to $1.14-1.19 \mathrm{~g} / \mathrm{cm}^{3}$, or $11.0-8.0 \%$ to the optimum values for cereals and row crops.

The highest yield, and correspondingly, the productivity of the crop rotation, was provided by the differentiated tillage, in which the deep plowing under sugar-beet inter-changes with the plowless shallow and surface tillage for intermediate early spring mixtures, winter barley, postmowing crops of grain corn and sunflower, with sowing of corn for forage in the previously unprepared soil after winter barley (Table 3 ).

Table 3

Productivity of 4-field row forage crop rotation at irrigation under the different methods of basic tillage of dark-chestnut soil of the experimental field of the Institute of Irrigated Agriculture of NAAS

\begin{tabular}{|c|c|c|c|c|c|c|}
\hline \multirow{2}{*}{ Field } & \multirow{2}{*}{ Crop } & \multicolumn{4}{|c|}{ Productivity by the systems, $t /$ ha } & \multirow{2}{*}{$\begin{array}{c}\mathbf{L S D}_{05}, \\
\text { t/ha }\end{array}$} \\
\hline & & 1 & 2 & 3 & 4 & \\
\hline \multirow[b]{2}{*}{1} & Annual herb mixtures & 32.4 & 33.9 & 33.9 & 34.5 & 2.9 \\
\hline & Post-mowing sunflower (seed) & 3.0 & 2.8 & 3.0 & 3.2 & 0.24 \\
\hline \multirow{2}{*}{2} & Annual herb mixtures & 31.1 & 31.4 & 32.3 & 32.5 & 2.6 \\
\hline & Post-mowing corn for forage & 38.9 & 40.6 & 42.6 & 40.9 & 3.0 \\
\hline \multirow[b]{2}{*}{3} & Winter barley (grain) & 4.2 & 4.4 & 4.4 & 4.2 & 0.3 \\
\hline & $\begin{array}{l}\text { Post-harvest corn for green } \\
\text { forage }\end{array}$ & 37.5 & 41.1 & 40.8 & 39.3 & 3.0 \\
\hline \multirow[t]{2}{*}{4} & Sugar-beet & 52.0 & 53.3 & 56.1 & 55.8 & 3.6 \\
\hline & $\begin{array}{l}\text { Crop rotation productivity, t/ha } \\
\text { of forage units }\end{array}$ & 13.8 & 14.24 & 14.7 & 14.6 & - \\
\hline
\end{tabular}

Note: 1-plowing at different depth, 2-plowless at different depth, 3-differentiated with slotting, 4-differentiated with plowing under the row crops.

\section{Systems of tillage in the crop rotation}

\section{for the enterprises working for the industrial processing}

During 2007-2018, on the background of continuous application of five basic tillage systems and three organo-mineral fertilizer systems, using as the fertilizer of leaf-stem mass of the crops of the crop rotation, the least experimentally studied and scientifically substantiated row crop rotations were investigated, which were found at the enterprises specializing in the production of cereals and industrial crops for industrial processing. Today, among the total are of the irrigated lands of 510 thousand ha, 265 thousand ha are covered by the row crops, which is $52.0 \%$. 
In these newly established large-scale enterprises, where there is no livestock industry, short crop rotations with soybean, corn for grain and sunflower have the priority. Cereal and perennial herbs occupy $10-15 \%$ of the croplands.

Crops, which are the part of row crop rotations, have different requirements for agro-physical properties and nutritional regimes, which are formed mainly under the influence of basic tillage and fertilization systems.

Nowadays, leaf-stem and root post-harvest residues of crops are the main source of fresh organic matter for the soil, which under the activity of microorganisms; oxidation and polymerization processes are transformed into new substances that are contained neither in the input organic residues, nor in microorganisms. According to the results of the research, it is established that on the non-fertilized background every year 4.0 to 4.8 tons of post-harvest residues are incorporated into the soil per 1 ha of the crop rotation area, on the background $-\mathrm{N}_{82.5} \mathrm{P}_{60}$ from 7.4 to 8.3 tons, and on the background of $\mathrm{N}_{120} \mathrm{P}_{60}$ application from 7.5 to $9.4 \mathrm{t} / \mathrm{ha}$.

Calculations of humus income into the soil from incorporated postharvest residues under the different basic tillage systems and nutrition background indicate that a negative humus balance is formed for all tillage systems, while the highest values were at plowless single-depth shallow $0.33 \mathrm{t} / \mathrm{ha}$ and the smallest $-0.16 \mathrm{t} / \mathrm{ha}$ for the differentiated-1 tillage with slotting on the depth of $38-40 \mathrm{~cm}$ once per rotation.

On the fertilized backgrounds with the application of $\mathrm{N}_{82.5} \mathrm{P}_{60}$ and $\mathrm{N}_{120} \mathrm{P}_{60}$ there was an increase in humus content. In the variants of multi-depth plow and differentiated-1 systems of the basic tillage, the increase of humus content was $+0.78 \mathrm{t} / \mathrm{ha}$, while under the plowless on different depth it was lower by $14.1 \%$ and was $+0.68 \mathrm{t} / \mathrm{ha}$.

At the systems of single-depth shallow plowless tillage and the differentiated-2, the humus content increase was also positive, while it was lower in comparison to the control by 51.3 and $38.5 \%$, respectively, at +0.38 and $+0.48 \mathrm{t} / \mathrm{ha}$.

To compensate the uptake of mineral nutrients with the crops, there was an input of total nitrogen, phosphorus and potassium into the soil with root and leaf residues. Thus, on a non-fertilized background, with basic plow tillage on the different depth (control), there was an income to the soil of $\mathrm{N}-21.8 ; \mathrm{P}_{2} \mathrm{O}_{5}-10.9 ; \mathrm{K}_{2} \mathrm{O}-26.7 \mathrm{~kg}$, and for the differentiated -1 with one slotting on $38-40 \mathrm{~cm}$ for the rotation $-\mathrm{N}-22 \mathrm{~kg} ; \mathrm{P}_{2} \mathrm{O}_{5}-11.0 ; \mathrm{K}_{2} \mathrm{O}-$ $26.4 \mathrm{~kg}$ per hectare of the crop rotation area. A similar tendency was observed on the fertilized backgrounds, while at the same time the indexes of mineral nutrition income were significantly higher.

At the application of the dose of $\mathrm{N}_{82.5} \mathrm{P}_{60}$, the income of nitrogen, phosphorus and potassium into the soil with plant residues was $70-80 \%$ higher than on the non-fertilized background.

Nitrogen, phosphorus and potassium income into the soil at the doses of $\mathrm{N}_{120} \mathrm{P}_{60}$ application averaged at the plow tillage on different depth to, 
respectively: $\mathrm{N}-42.6 \mathrm{~kg} / \mathrm{ha} ; \mathrm{P}_{2} \mathrm{O}_{5}-21.3$ and $\mathrm{K}_{2} \mathrm{O}-51.1 \mathrm{~kg} / \mathrm{ha}$, that is 91.4-95.4\% more than in the non-fertilized background (control).

At the multi-depth plowless and differentiated-1 systems of the basic tillage, the reduction of mineral nutrition inputs in comparison to the control was not significant and averaged to $1.8 \%, 1.5$ and $1.7 \%$.

Only under the system of single-depth shallow plowless tillage with its long application in the crop rotation and on all the fertilization backgrounds, there was a significant decrease in the income of all mineral nutrients in comparison to the system of plow tillage on different depth.

In general, the application of mineral fertilizers and the use of postharvest (leaf and stem) residues as fertilizers contributed to the creation of different levels of content of available forms of mineral nutrients at the beginning of the spring regrowth of winter crops and emergence of spring cereals and industrial crops seedlings.

At the non-fertilized background with the use of post-harvest residues as a fertilizer at the beginning of vegetation of the crops of the crop rotation, the highest content of mobile mineral nutrition compounds was in the variant of the plowing basic tillage system: nitrates $29.8 \mathrm{mg} / \mathrm{kg}$ of soil, mobile phosphorus of 31.8 and exchangeable potassium of $289 \mathrm{mg} / \mathrm{kg}$ of soil.

The application of mineral fertilizers with the dose of $\mathrm{N}_{82.5} \mathrm{P}_{60}$ ensured the increase in the content of all the elements of mineral nutrition, while at the same time the advantage remained at the system of differentiated by the depth plowing.

The highest nitrate content of $68.4 \mathrm{mg} / \mathrm{kg}$ of soil, mobile phosphorus of 46.4 and exchangeable potassium of $358 \mathrm{mg} / \mathrm{kg}$ of soil was formed under the application of mineral fertilizers with the dose of $\mathrm{N}_{120} \mathrm{P}_{60}$ per hectare of the crop rotation area under the multi-depth plow system of tillage.

Multi-depth plowless and differentiated tillage systems provided close performance with the multi-depth plow tillage system, and only the single-depth shallow plowless loosening system led to a significant decrease in the content of available mineral nutrients in the soil layer of $0-40 \mathrm{~cm}$ at the beginning of the spring vegetation of the crops of the rotation.

Before the harvesting, the nitrate content of the soil decreased on all the nutritional backgrounds, while at the same time the smallest indexes were on the non-fertilized background.

It should be mentioned that the basic tillage affected the content of mobile phosphorus and exchangeable potassium. It was the lowest at the plowless shallow single-depth tillage and reached $27.9-38.3$ and $259-315 \mathrm{mg} / \mathrm{kg}$ at the beginning of the growing season and 18.7-21.9 and $214-254 \mathrm{mg} / \mathrm{kg}$ of the soil, respectively, before the harvesting. Before the harvesting, their content reduced and remained within the range of moderate supply.

Analyzing the crop productivity data in the crop rotation on the non-fertilized background it was found that its highest values, expressed in the grain units per $1 \mathrm{ha}$ of the crop rotation area, were obtained at the plowing tillage on the different depth -3.95 , and differentiated- $1-4.11 \mathrm{t} / \mathrm{ha}$ of grain units. 
Under the use of the different-depth plowless tillage and the differentiated-2 basic tillage, slightly lower yields of grain units of 3.56 and $3.47 \mathrm{t} / \mathrm{ha}$ were obtained. A significant decrease in productivity by $27.8 \%$ in comparison to the control was observed in the variant of shallow singledepth plowless tillage (table. 4).

Table 4

Crop yields and productivity of 4-field crop rotation at irrigation at different fertilizer doses and basic tillage systems

\begin{tabular}{|c|c|c|c|c|c|c|}
\hline \multirow[b]{2}{*}{$\begin{array}{c}\text { Basic tillage } \\
\text { system } \\
\text { (factor A) }\end{array}$} & \multirow[b]{2}{*}{$\begin{array}{l}\text { Fertilizers dose } \\
\quad \text { (factor B) }\end{array}$} & \multicolumn{4}{|c|}{ Yield, t/ha } & \multirow[b]{2}{*}{$\begin{array}{c}\text { Productivity } \\
\text { in grain units, } \\
\text { t/ha }\end{array}$} \\
\hline & & $\begin{array}{l}\text { winter } \\
\text { wheat }\end{array}$ & $\begin{array}{c}\text { grain } \\
\text { corn }\end{array}$ & soybean & $\begin{array}{c}\text { grain } \\
\text { sorghu } \\
\text { m }\end{array}$ & \\
\hline \multirow{3}{*}{$\begin{array}{c}\text { Plow } \\
\text { (control) }\end{array}$} & $\begin{array}{c}\text { no fertilizers } \\
\text { (control) }\end{array}$ & 3.15 & 4.26 & 2.76 & 2.89 & 3.95 \\
\hline & $\mathrm{N}_{82.5} \mathrm{P}_{60}$ & 6.01 & 11.43 & 3.68 & 6.90 & 8.05 \\
\hline & $\mathrm{N}_{120} \mathrm{P}_{60}$ & 6.81 & 14.44 & 4.34 & 7.09 & 9.36 \\
\hline \multirow{3}{*}{$\begin{array}{l}\text { Plowless on } \\
\text { different depth }\end{array}$} & $\begin{array}{c}\text { no fertilizers } \\
\text { (control) }\end{array}$ & 3.01 & 3.81 & 2.48 & 2.51 & 3.56 \\
\hline & $\mathrm{N}_{82.5} \mathrm{P}_{60}$ & 5.53 & 10.81 & 3.34 & 6.58 & 7.55 \\
\hline & $\mathrm{N}_{120} \mathrm{P}_{60}$ & 6.25 & 13.64 & 3.98 & 6.81 & 8.78 \\
\hline \multirow{3}{*}{$\begin{array}{c}\text { Plowless } \\
\text { single-depth }\end{array}$} & $\begin{array}{c}\text { no fertilizers } \\
\text { (control) }\end{array}$ & 2.70 & 3.05 & 1.77 & 2.04 & 2.85 \\
\hline & $\mathrm{N}_{82.5} \mathrm{P}_{60}$ & 5.26 & 8.16 & 2.41 & 4.59 & 5.82 \\
\hline & $\mathrm{N}_{120} \mathrm{P}_{60}$ & 5.91 & 10.08 & 2.83 & 4.76 & 6.70 \\
\hline \multirow{3}{*}{ Differentiated-1 } & $\begin{array}{c}\text { no fertilizers } \\
\text { (control) }\end{array}$ & 3.24 & 4.46 & 2.81 & 3.03 & 4.11 \\
\hline & $\mathrm{N}_{82.5} \mathrm{P}_{60}$ & 6.08 & 11.81 & 3.79 & 7.51 & 8.50 \\
\hline & $\mathrm{N}_{120} \mathrm{P}_{60}$ & 6.90 & 14.82 & 4.31 & 7.70 & 9.75 \\
\hline \multirow{3}{*}{ Differentiated-2 } & $\begin{array}{l}\text { no fertilizers } \\
\text { (control) }\end{array}$ & 2.89 & 3.73 & 2.40 & 2.54 & 3.47 \\
\hline & $\mathrm{N}_{82.5} \mathrm{P}_{60}$ & 5.34 & 10.28 & 3.37 & 6.28 & 7.28 \\
\hline & $\mathrm{N}_{120} \mathrm{P}_{60}$ & 6.13 & 13.01 & 3.94 & 6.43 & 8.46 \\
\hline
\end{tabular}

The productivity of the crops by the variants of the ways and depth of the basic tillage at the application of mineral fertilizers with the dose of $\mathrm{N}_{82.5} \mathrm{P}_{60}$ increased to $112.1 \%$, and the increase of the dose of fertilizers to $\mathrm{N}_{120} \mathrm{P}_{60}$ ensured its raise to $146.6 \%$, compared to the non-fertilized backgrounds.

The increase of the dose of mineral fertilizers on the background with the application of N120P60 was favorable for the growth of productivity by $14.7-16.3 \%$ in comparison to the N82.5P60 nutritive background.

In the structure of the expenditures for cultivation its share varies from 2 to $10 \%$, while at the same time it largely depends on the productivity of most crops on irrigated lands. Assessing the effectiveness of low-cost, shallow and multidepth soil tillage systems in the crop rotation, it should be noted that having provided significant cost savings for their implementation, they have little impact on the overall expenditures for crop production on the whole. So, if on a non-fertilized background at the systems of different-depth plowing basic tillage (control), the expenditures for cultivation technology averaged to 10.47 thousand 
UAH per hectare of the crop rotation area, then for the systems of different-depth plowless tillage and differentiated-1 with one slotting per the rotation and differentiated-2 with one plowing per the rotation (variants $2,4,5$ ), they were less by $1.5,2.1$ and $2.3 \%$, respectively.

At the single-depth shallow plowless tillage system (variant 3), expenditures have decreased by $3.0 \%$. The cost of gross production per hectare of the crop rotation area for various plowing systems on the nonfertilized background was 17.74 thousand UAH. In the variant of the differentiated-1 basic tillage system, it was higher and averaged to 18.61 thousand UAH, or increased by $4.9 \%$ with a profitability level of 71.4 and $82.9 \%$, respectively.

The lowest payback of crop cultivation technology in the irrigated crop rotation was on the unfavorable background of the single-depth shallow plowless tillage system, with a gross output of 12.65 thousand UAH, which is lower than the control by $28.7 \%$ with a profitability level of $26.4 \%$ (Table 5).

Table 5

Economic efficiency of crop cultivation technologies under different tillage and fertilizer systems

\begin{tabular}{|c|c|c|c|c|c|c|}
\hline № & $\begin{array}{l}\text { Basic tillage } \\
\text { system in the } \\
\text { crop rotation }\end{array}$ & $\begin{array}{c}\text { Fertilizers } \\
\text { dose }\end{array}$ & $\begin{array}{c}\text { Gross } \\
\text { product } \\
\text { value }\end{array}$ & $\begin{array}{l}\text { Expendit } \\
\text { ures, } \\
\text { UAH }\end{array}$ & $\begin{array}{l}\text { Profit, } \\
\text { UAH/ha }\end{array}$ & $\begin{array}{c}\text { Profitabilit } \\
\text { y, \% }\end{array}$ \\
\hline \multirow[t]{3}{*}{1} & \multirow{3}{*}{$\begin{array}{c}\text { Plow } \\
\text { (control) }\end{array}$} & $\begin{array}{c}\text { no } \\
\text { fertilizers } \\
\text { (control) }\end{array}$ & $17,743.0$ & $10,470.7$ & $7,272.3$ & 71.4 \\
\hline & & $\mathrm{N}_{82.5} \mathrm{P}_{60}$ & $34,984.3$ & $13,827.3$ & $21,157.0$ & 152.7 \\
\hline & & $\mathrm{N}_{120} \mathrm{P}_{60}$ & $40,752.7$ & $15,016.3$ & $25,736.0$ & 170.5 \\
\hline \multirow[t]{3}{*}{2} & \multirow{3}{*}{$\begin{array}{l}\text { Plowless on } \\
\text { different depth }\end{array}$} & $\begin{array}{c}\text { no } \\
\text { fertilizers } \\
\text { (control) }\end{array}$ & $16,119.0$ & $10,312.3$ & $5,806.7$ & 57.9 \\
\hline & & $\mathrm{N}_{82.5} \mathrm{P}_{60}$ & $32,757.0$ & $13,631.7$ & $19,125.3$ & 140.3 \\
\hline & & $\mathrm{N}_{120} \mathrm{P}_{60}$ & $38,285.3$ & $14,832.7$ & $23,452.7$ & 157.5 \\
\hline \multirow[t]{3}{*}{3} & \multirow{3}{*}{$\begin{array}{l}\text { Plowless single- } \\
\text { depth }\end{array}$} & $\begin{array}{c}\text { no } \\
\text { fertilizers } \\
\text { (control) }\end{array}$ & $12,654.0$ & $10,155.7$ & $2,498.3$ & 26.4 \\
\hline & & $\mathrm{N}_{82.5} \mathrm{P}_{60}$ & $25,479.3$ & $13,494.3$ & $11,985.0$ & 89.4 \\
\hline & & $\mathrm{N}_{120} \mathrm{P}_{60}$ & $29,008.3$ & $14,701.3$ & $14,307.0$ & 97.1 \\
\hline \multirow[t]{3}{*}{4} & \multirow[t]{3}{*}{ Differentiated-1 } & $\begin{array}{c}\text { no } \\
\text { fertilizers } \\
\text { (control) }\end{array}$ & $18,606.0$ & $10,248.7$ & $8,357.3$ & 82.9 \\
\hline & & $\mathrm{N}_{82.5} \mathrm{P}_{60}$ & $36,860.7$ & $13,494.3$ & $23,366.3$ & 172.6 \\
\hline & & $\mathrm{N}_{120} \mathrm{P}_{60}$ & $42,397.7$ & $14,794.0$ & $27,602.3$ & 185.0 \\
\hline \multirow[t]{3}{*}{5} & \multirow[t]{3}{*}{ Differentiated-2 } & $\begin{array}{c}\text { no } \\
\text { fertilizers } \\
\text { (control) } \\
\end{array}$ & $15,697.3$ & $10,224.7$ & $5,472.7$ & 55.6 \\
\hline & & $\mathrm{N}_{82.5} \mathrm{P}_{60}$ & $32,083.3$ & $13,537.0$ & $18,546.3$ & 136.2 \\
\hline & & $\mathrm{N}_{120} \mathrm{P}_{60}$ & $37,488.3$ & $14,750.0$ & $22,738.3$ & 152.7 \\
\hline
\end{tabular}




\section{Efficiency of minimized systems of basic tillage and sowing in previously unprepared soil in grain-row crop rotation}

Mastering of soil-protective resource-saving and zero systems of basic tillage with wide use of high-performance tools of the plow, chisel, disk type and drills that combine tillage with sowing have been conducted at Askanian Research Station of the Institute of Irrigated Agriculture of NAAS since 2008.

With this purpose, the efficiency of long-term use of systems was studied in the stationary irrigated field in short crop rotation with soybean, winter wheat, corn and barley: differentiated tillage, where during the rotation plowing on the depth of $28-30 \mathrm{~cm}$ under row crops was changed by the shallow $(12-14 \mathrm{~cm})$ disk loosening under winter cereals; single-depth shallow $(12-14 \mathrm{~cm})$ disking for all the crops of the rotation; different-depth chisel $(23-25-28-30 \mathrm{~cm})$ loosening during the crop rotation; and the constant use of zero tillage, which combines cultivation with the sowing of the crop in one aggregate without previous tillage.

To evaluate the efficiency of the application of minimized and zero systems of basic tillage, the studies of agro-physical properties, water and nutrient regime of the soil and productivity of the crops were conducted.

Determination of the bulk density of the soil before the experiment setting (2008) showed that it was the highest in the soil layer of $0-40 \mathrm{~cm}$ at the use of sowing crops into the previously untreated soil and was $1.42 \mathrm{~g} / \mathrm{cm}^{3}$.

A very significant compaction was also observed under the use of shallow plowless tillage on the depth of $12-14 \mathrm{~cm}-1.41 \mathrm{~g} / \mathrm{cm}^{3}$. At these tillage systems, the most compacted soil layer was $10-20 \mathrm{~cm}$ and was respectively $1.44 \mathrm{~g} / \mathrm{cm}^{3}$ and $1.46 \mathrm{~g} / \mathrm{cm}^{3}$.

In general, changes in agro physical conditions, water and nutrient regime under the different systems of basic tillage and fertilizer doses had a significant impact on the crop production and the crop rotation productivity (Table 7).

Table 7

Crop yields and crop rotation productivity under different tillage systems and fertilizer doses, average for 2009-2018

\begin{tabular}{|c|c|c|c|c|c|}
\hline \multirow[b]{2}{*}{ Basic tillage system } & \multicolumn{4}{|c|}{ Crop yields of the crop rotation, $t / h a$} & \multirow[b]{2}{*}{$\begin{array}{l}\text { Productivity of } \\
\text { crop rotation, } \\
\text { (the grain } \\
\text { units) }\end{array}$} \\
\hline & $\begin{array}{c}\text { winter } \\
\text { wheat } \\
+ \\
\text { mustard } \\
\text { for } \\
\text { green } \\
\text { manure } \\
\end{array}$ & $\begin{array}{l}\text { grain } \\
\text { corn }\end{array}$ & $\begin{array}{c}\text { winter } \\
\text { barley }+ \\
\text { mustard } \\
\text { for } \\
\text { green } \\
\text { manure }\end{array}$ & soybean & \\
\hline \multicolumn{6}{|c|}{ fertilizers dose of $\mathrm{N}_{60} \mathrm{P}_{40}$} \\
\hline Differentiated & 6.19 & 9.32 & 5.37 & 3.34 & 6.59 \\
\hline Plowless shallow & 5.85 & 7.94 & 5.32 & 3.28 & 6.12 \\
\hline $\begin{array}{c}\text { Different-depth } \\
\text { plowless }\end{array}$ & 6.01 & 8.69 & 5.42 & 3.35 & 6.40 \\
\hline Zero & 5.28 & 6.56 & 4.52 & 2.90 & 5.28 \\
\hline
\end{tabular}




\begin{tabular}{|c|c|c|c|c|c|}
\hline \multicolumn{7}{|c|}{ fertilizers dose of $\mathbf{N}_{\mathbf{9 7 . 5}} \mathbf{P}_{\mathbf{4 0}}$} \\
\hline Differentiated & 6.68 & 10.34 & 5.84 & 3.73 & 7.25 \\
\hline Plowless shallow & 6.36 & 9.30 & 5.86 & 3.76 & 6.92 \\
\hline $\begin{array}{c}\text { Different-depth } \\
\text { plowless }\end{array}$ & 6.40 & 10.26 & 5.94 & 3.85 & 7.23 \\
\hline Zero & 5.67 & 7.56 & 4.88 & 3.28 & 5.88 \\
\hline \multicolumn{7}{|c|}{ fertilizers dose of $\mathbf{N}_{\mathbf{1 3 5}} \mathbf{P}_{\mathbf{4 0}}$} \\
\hline Differentiated & 6.92 & 11.08 & 6.30 & 3.87 & 7.66 \\
\hline Plowless shallow & 6.78 & 9.95 & 6.32 & 3.82 & 7.33 \\
\hline $\begin{array}{c}\text { Different-depth } \\
\text { plowless }\end{array}$ & 6.83 & 11.02 & 6.34 & 3.99 & 7.69 \\
\hline Zero & 6.14 & 8.09 & 5.28 & 3.27 & 6.22 \\
\hline
\end{tabular}

\section{CONCLUSIONS}

The basic tillage in the arid conditions of Southern moderately dry, Drysteppe and very Dry soil-ecological subzones of the Steppe zone should ensure, first of all, rational use of land, water and material resources, high crop yields, productivity of crop rotations, preservation of soil fertility and improvement of the ameliorative conditions of irrigated lands.

Prolonged use of differentiated systems of basic tillage in crop rotation at irrigation has ensured, on the background of application of different doses of mineral fertilizers, the formation of the highest level of productivity. Not significant decrease was observed in the variants of different-depth chisel and single-depth shallow disk loosening, mainly due to the yield of corn grain.

Sowing in untreated soil over 10 years of the research has led to a significant decrease in the crop yields and the crop rotation productivity in general.

\section{SUMMARY}

The article reflects the results of the study on the effect of basic tillage and fertilization on the productivity of the irrigated crop rotations.

The aim of the study was the determination of the effect of basic tillage and fertilization on the productivity of the irrigated crop rotations of the South of Ukraine. The task of the study was to determine the impact of the studied factors on the yielding indexes, and energy efficiency of the crops cultivation technologies at irrigation.

Field experiments were carried out with accordance to the methodology of research work. Cultivation technologies of the crops in the irrigated crop rotations were generally accepted for the conditions of the South of Ukraine.

The regulations of the impact of basic tillage on the agro physical properties, nutritive regime of the soil, which contributed to the creation of 
favorable conditions for growth, development and productivity of the studied crops, were established. It was proved that application of the plowless basic tillage provides the increase of winter wheat grain yield within $0.1-0.6 \mathrm{t} / \mathrm{ha}$. At the same time, row crops react negatively on the plowless tillage that was evident by the decrease in the yield of soybean by $0.4-0.5$; corn - by 1.0-1.4 t/ha. The increase of fertilization to $\mathrm{N}_{97,5} \mathrm{P}_{60} \mathrm{~kg}$ of the active substances per 1 ha of the cropland provided the increase in the yields of all the crops within the crop rotation with the maximum productivity indexes $124.4 \mathrm{GJ} / \mathrm{ha}$ on the variants with plowing different-depth and differentiated systems of tillage in the crop rotation. The ANOVA proved that grain yields of winter barley and corn were mostly affected by nitrogen fertilizers, by 74.9 and $54.9 \%$ respectively from the whole share of the weight of these crop productivity formation, and different schemes of basic tillage had such strength of the impact: on barley $-21.1 \%$; on corn $-36.1 \%$.

\section{REFERENCES}

1. Класифікація грунтів України. К.: Аграрна наука, 2005. 299 с.

2. Система ведення сільського господарства Херсонської області. Херсон: «Айлант», 2004. 164 с.

3. Балюк С. А., Ромащенко М. І., Трускавецький Р. С. Меліорація грунтів систематика, перспективи, інновації. Херсон, 2015. 667 с.

4. Коваленко П. І. Інтегроване управління водними і земельними ресурсами на меліорованих територіях. Київ: Аграрна наука, 2009. 783 с.

5. Ромащенко М. І., Вожегова Р. А., Шатковський А. П. Наукові засади розвитку аграрного сектора економіки південного регіону. Херсон: Олді- плюс, 2017. 437 с.

6. Бурзі К. Е., Красутська Н. В., Синицина Н. П., Сафонова О. П. Сольовий режим грунтів Інгулецького зрошуваного масиву. Зрошуване землеробство. 1971. Вин. 12. С. 63-67.

7. Балюк С. А., Ромащенко М. І., Сташук В. А. Наукові основи охорони та раціонального використання зрошуваних земель України. Київ: Аграрна наука, 2009. 620 с.

8. Вожегова Р. А., Сташук В. А., Заришняк А. С. Системи землеробства на зрошуваних землях. Київ: Аграрна наука, 2014. 359 с.

9. Малярчук М. П., Нижеголенко В. М., Резніченко Н. Д., Воронюк Л. А. Системи землеробства в умовах південного посушливого та сухого степу. Збірник матеріалів Міжнародної науково-практичної конференції «Наукові засади ефективного ведення степового землеробства в умовах змін клімату» 28-29 травня 2015 р. Херсон: Грінь Д.С., 2015. С. 141-145. 
10. Малярчук М. П., Вожегова Р. А., Марковська О. С. Формування систем основного обробітку грунту в агробіоценозах на меліорованих землях південної посушливої та сухо степової грунтовоекологічних підзон України. Навчальний посібник. Херсон: Айлант, 2012. $180 \mathrm{c}$.

11. Малярчук М. П., Писаренко П. В., Мишукова Л. С., Малярчук А. С. Котельников Д. І., Нижеголенко В. М. Ефективність мінімізованих способів основного обробітку і сівби в попередньонеоброблений грунт при вирощуванні кукурудзи на зрошуваних землях. Зрошуване землеробство: збірник наукових праць. Херсон: Айлант, 2013. Вип. 59. С. 36-38.

12. Малярчук М. П. Система обробітку грунту. Наукові основи охорони та раціонального використання зрошуваних земель України. Київ: Аграрна наука, 2009. С. 299-313.

13. Малярчук М. П. Формування систем обробітку грунту в сівозмінах на меліорованих землях Південного Степу України. Посібник Українського хлібороба. 2014.

\section{Information about the author:} Biliaieva I. M., Doctor of Agricultural Sciences, Senior Researcher, Institute of Irrigated Agriculture of the National Academy of Agrarian Sciences of Ukraine Kherson, Naddniprianske, 73483, Ukraine 